\begin{tabular}{ccc}
\hline & $\begin{array}{r}\text { International Journal of Health Services, } \\
\text { Research and Policy } \\
\text { www.dergipark.org.tr/ijhsrp }\end{array}$ \\
$\begin{array}{c}\text { INTESEG } \\
\begin{array}{c}\text { ENGINATIONAL } \\
\text { SCIENCE ANG, } \\
\text { EDUCATION GROUP }\end{array}\end{array}$ & e-ISSN: 2602-3482 $\quad$ DOI:10.23884/ijhsrp.2019.4.2.02 & IJHSRP \\
\hline
\end{tabular}

Research Article

\title{
JOB SATISFACTION AS AN OBJECTIVE INDICATOR OF WORK MOTIVATION AMONG INTENSIVE CARE NURSES
}

\author{
"Dejan ŽIVANOVIĆ' ${ }^{1}$ (i), Jovan JAVORAC ${ }^{2}$ (i), \\ Branislava BRESTOVAČKI SVITLICA ${ }^{2,3}$ (D), Svetlana STOJKOV ${ }^{I}$ (D) \\ ${ }^{1}$ College of Vocational Studies for Education of Preschool Teachers and Sports Trainers, Dept. of \\ Medical Sciences, Biotechnology and Chemistry, Subotica, Serbia \\ ${ }^{2}$ Faculty of Medicine, University of Novi Sad, Serbia \\ ${ }^{3}$ Institute of Child and Adolescent Health Care of Vojvodina, Novi Sad, Serbia \\ *Corresponding author; zivanovic_dejan@yahoo.com
}

\begin{abstract}
Job satisfaction is a complex psychological phenomenon and an extremely important factor in work quality and employees' work motivation. Considering that factors contributing to job (dis)satisfaction also affect the work motivation, the level of job satisfaction is used in this psychometric cross-sectional study as an indicator of work motivation among a sample of 71 intensive care nurses in one of the university hospitals in Belgrade, Serbia. The level of job satisfaction was assessed by an adapted and customized survey in Serbian language, based on famous Spector's Job Satisfaction Survey (JSS). Analyzing collected data, a high level of job dissatisfaction among participants of our study was founded. Considering obtained results in the light of the competent literary sources' allegations which suggest that job satisfaction level reliably indicate the level of work motivation at the same time, we concluded that work motivation in the observed sample was very poor at the moment of conducting this study, clearly indicating the need for a more comprehensive research of work motivation among Serbian nursing practitioners in future.
\end{abstract}

Keywords: intensive care nurse; job; motivation; satisfaction

Received: April 3, 2019

Accepted: July 4, 2019

\section{Introduction}

Job satisfaction is a complex psychological phenomenon and an extremely important factor in work quality and employees' work motivation. In essence, job satisfaction represents a subjective perception of opportunities to achieve important aspects of work and life while performing a particular job, and can be defined as a pleasant, positive emotional state that arises as a result of work experience and motivates an employee to continue with work in a particular profession, or at particular workplace [1-3]. In the past, determining the potential correlation between job satisfaction and work motivation has been the subject of numerous studies in the field of applied psychology and related sciences. In many available studies, researchers have found that factors contributing to job (dis)satisfaction also affect the work motivation of employees, at the same time [4-6]. Considering this scientific fact, the level of job satisfaction is used nowadays as an objective indicator of work motivation in all professions, as well as in nursing, one of the most stressful professions of the contemporary society that requires simultaneous mental, physical and emotional engagement, especially in intensive care units (ICU) [7, 8]. 
Regardless of the type of professional activity, the subjective experience of job satisfaction is not affected only by the nature of performed work and conditions of the work environment, but also by personal expectations of the employee in relation to a particular job [1]. Although the assumed factor of work motivation among all health workers, and therefore of nurses, primarily should be the desire to help another human being, researches has shown that job satisfaction among this type of helping professionals objectively depends on several independent or interrelated factors - belonging to a particular gender, age of employees, degree of formal education, length of service, working place conditions, type of work, length and organization of working hours, manner of management, promotion opportunities, as well as the amount of material compensation for the work performed [9]. Various studies have shown that, compared with other humanist-oriented professions, all healthcare professionals are exposed to a significantly greater risk of professional dissatisfaction, especially those who are exposed to the prolonged influence of occupational stressors, like ICU nurses. In intensive care units, nurses are dealing daily with different needs, problems, sufferings, and, finally, the death of critically ill patients. Over time, the synergistic effect of all these factors inevitably leads to exhaustion of nurse's emotional potentials, which greatly affects both long-term job satisfaction and work motivation [10-12]. Because of that, job satisfaction among ICU nurses cannot be observed only as an isolated individual attitude in regard to the current job, but only as a complex phenomenon based on the synergistic psycho-emotional effect of all specific workplace factors, strongly influencing employees in the motivational sphere and in overall attitude toward work. [13].

Assessing the level of job satisfaction is of great importance for improving the general quality of professional activity and achieving better professional performance. In countries with the strongly developed health system, it is not uncommon for management of healthcare institutions to use the job satisfaction test as an objective instrument for assessing employee work motivation, general efficiency of work organization, and to identify failures in managing the institution or its smaller organizational segments [1]. The level of job satisfaction among ICU nurses is directly related to the presence of professional burnout syndrome, the frequency of work absenteeism, the quality of professional communication and overall quality of interpersonal relationships among employees at different levels of the organizational scale, but also the degree of professional efficiency of the institutional work organization which is expected to satisfy current and potential needs of healthcare users. Based on different researches, intensive care units are often marked as workplaces with a low level of job satisfaction among employees, especially members of the nursing profession [14]. Due to the nonfulfillment of personal expectations regarding work and various forms of psycho-emotional pressure on the workplace, an employee often experiences a subjective feeling of exhaustion, fatigue and emotional gaps that lead not only to professional dissatisfaction and loss of work motivation in a very short time, but also to creation of ideal base for development of burnout syndrome - a specific psycho-emotional construct that can have unpredictable and potentially dangerous consequences, especially if patientrelated activities of health professionals directly affect life and death issues, such as nurses employed in intensive care units $[14,15]$. Available researches among participants from the nursing profession show that "nurse job dissatisfaction has been the primary predictor of intent to leave" [16]. Unfortunately, in low-income societies, the inability to leave a permanent job and the long-term job dissatisfaction often lead to permanent loss of work motivation among ICU nurses; professional errors can become more and more dangerous over time, and even can endanger patient' life in some situations [7,17]. However, despite all the above, there is almost no available data in the literature regarding job satisfaction among 
ICU nurses in Serbia and the surrounding countries, which was the main reason for conducting this cross-sectional study. The aim of this study was to assess the level of work motivation among ICU nurses by analyzing the level of ten different domains of job satisfaction.

\section{Methods}

\subsection{Sample and Design of the Study}

This research was designed in the form of a psychometric cross-sectional study, which included a sample of 71 ICU nurses in total. The study included nurses employed in currently existing intensive care units of the clinics and hospitals for surgery, urology, internal medicine, pediatrics, gynecology and obstetrics, and otorhinolaryngology in one of the university hospitals in Belgrade, Serbia, in July of 2017.

\subsection{Research Instrument}

In this study, only factors related to the process of working and workplace were considered in assessing the level of job satisfaction. Regarding sociodemographic data, the respondents are required only to indicate the affiliation of a particular gender and age. The instrument of the research survey in Serbian language (Mladenovic, 2013.), based on Job Satisfaction Survey (JSS), originally created by American psychologist, Professor Paul E. Spector from University of South Florida (18). The survey is constructed in order to determine universal domains of job satisfaction. According to domestic and foreign literature, the original survey developed a Cronbach-alpha coefficient higher than 0.70, which makes it relevant for job satisfaction testing in different professions. The original survey with scoring instructions is available to researchers free of charge, only for non-commercial purposes, on following web page: http://www.shell.cas.usf.edu/pspector/scales/jsspag/html.

The survey contains 36 statements grouped in 10 domains: general job satisfaction (1), salary (2), promotion (3), supervision (4), benefits (5), rewarding (6), working conditions (7), associates 8), nature of work (9) and communication (10). The respondents were ordered to choose only one of the offered responses on the Likert scale which best describes their stand about the above statement, namely: 1 (totally disagree), 2 (partially disagree), 3 (slightly disagree), 4 (slightly agree), 5 (partially agree), and 6 (completely agree). The number in front of the statement also indicates the number of points the study participant received for this question, except for the negatively formulated statements, under the ordinal number: $2,4,6,8,10,12,14,16,18,19,21,23,24,26,29,31,32,34,36$, for which the points of the participant are calculated in the following way: $1=6 ; 2=5 ; 3=4 ; 4=3 ; 5=2 ; 6=1$. The unique score is calculated for each domain, obtained by adding points for statements related to a certain domain, after converting points for negatively formulated statements, as follows:

1. general job satisfaction (all statements in the survey):

- $36-108$ points (dissatisfied),

- $109-144$ points (ambivalent stand),

- $145-216$ points (satisfied);

2. salary (statements: $1,10,19,28$ ),

3. promotion (statements: $2,11,20,33$ ),

4. supervision (statements: $3,12,21,30$ ),

5. benefits (statements: $4,13,22,29$ ),

6. rewarding (statements: $5,14,23,32$ ),

7. working conditions (statements: $6,15,24,31$ ),

8. associates (statements: 7, 16, 25, 34), 
9. nature of work (statements: $8,17,27,35$ ),

10. communication (statements: $9,18,26,36$ ):

- $4-12$ points (dissatisfied),

- $13-16$ points (ambivalent stand),

- $17-24$ points (satisfied).

\subsection{Ethical Consideration}

Purpose, ethics, scientific basis and other relevant issues related to this research have been considered and approved both by the Ethical Committee of the Faculty of Medicine, University of Novi Sad and by the Ethical Committee of the institution where the research has been carried out, documented by a written decision available. Participants have been included in the research on the voluntary basis exclusively, and the obtained information warranted secret. Each participant was informed about the aim of the study in the survey preamble.

\subsection{Statistical Analysis}

In order to generate descriptive statistics, results were statistically analyzed by using the SPSS Statistical Package for Windows, version 16. The obtained results are presented in tables and, depending on their type, expressed by absolute and relative numbers, calculated mean values, (the arithmetical mean, the median) and variability measures (standard deviation - SD, coefficient of variation - CV, range). As the research is dealing with attributive characteristics, the difference between expected and observed frequencies in all investigated categories has been determined using the Chi-square $\left(\mathrm{x}^{2}\right)$ independence test. Minimum significance level in this study was set to 0.05 .

\section{Results}

\subsection{Basic sociodemographic data}

In the examined sample, statistically significant differences have been registered in the subjects' gender distribution - 23 males (32.4\%), and 48 females (67.6\%), $p<0.05$. The mean age of the examined subjects was 33.8 years, with a slightly younger mean age of males - approximately 31.3 years (SD, 5.9; $\mathrm{CV}<30 \%$ ) as compared to the mean females ${ }^{6}$ age - approximately 36.3 years (SD, 9.5; CV $<30 \%$ ); however, by testing, these differences have been established as statistically insignificant $(p>0.05)$. Gender and age distribution of the study participants is presented in Tab. 1.

Table 1. Participants 'gender and age distribution

\begin{tabular}{|c|c|c|c|c|c|c|c|c|}
\hline \multirow{2}{*}{ GENDER } & \multirow{2}{*}{$\mathrm{N}$} & $\%$ & $\overline{\mathrm{x}}$ & $\mathrm{SD}$ & $\mathrm{CV} \%$ & Med & Min. & Max. \\
\hline males & 23 & 32.4 & 31.3 & 5.9 & 18.8 & 31 & 22 & 43 \\
\hline females & 48 & 67.6 & 36.3 & 9.5 & 26.2 & 34 & 20 & 53 \\
\hline$\sum$ & 71 & 100.0 & 33.8 & & \multicolumn{7}{|c|}{$>0.05$} & & \\
\hline$p$ & \multicolumn{3}{|c|}{$<0.05$} & \multicolumn{6}{|c|}{ AGE } \\
\hline
\end{tabular}

Note: $\mathrm{N}$ - subjects in total; $\overline{\mathrm{x}}-$ mean arithmetic value, SD - standard deviation, $\mathrm{CV} \%$ - variation coefficient, Med - median, Min. - minimum value, Max. - Maximum value

\subsection{Job satisfaction analysis}

The distribution of study participants based on general job satisfaction points to the statistically significant predominance of those who are not satisfied with the current job ( $\mathrm{p}<0.05)$. General job dissatisfaction was registered in a total of 53 or $74.6 \%$ of study participants (SD, 13.6, 
$\mathrm{CV}<30 \%$ ); the ambivalent stand towards the general job satisfaction was observed in seven, i.e. $9.9 \%$ of examined subjects (SD, 6.3, CV<30\%), while only 11 of them, or $15.5 \%$ (SD, 16.1, CV<30\%) are satisfied with the current job in general sense (Tab. 2.)

Table 2. Distribution of general job satisfaction (GJS) among participants

\begin{tabular}{|c|c|c|c|c|c|c|c|c|}
\hline GJS level (x) & $\mathrm{N}$ & $\%$ & $\overline{\mathrm{x}}$ & $\mathrm{SD}$ & $\mathrm{CV} \%$ & Med & Min. & Max. \\
\hline Dissatisfied (36-108 p.) & 53 & 74.6 & 79.7 & 13.6 & 17.1 & 79 & 51 & 107 \\
\hline Ambivalent (109-144 p.) & 7 & 9.9 & 125.4 & 6.3 & 5.01 & 123 & 116 & 135 \\
\hline Satisfied (145-216 p.) & 11 & 15.5 & 160.9 & 16.1 & 10.0 & 157 & 145 & 192 \\
\hline$\sum$ & 71 & 100.0 & \multicolumn{7}{|c|}{$<0.05$} \\
\hline$p$ & \multicolumn{7}{|c|}{} & \\
\hline
\end{tabular}

Note: $\mathrm{N}$ - subjects in total; $\overline{\mathrm{x}}$ - mean arithmetic value, $\mathrm{SD}$ - standard deviation, $\mathrm{CV} \%$ - variation coefficient, Med - median, Min. - minimum value, Max. - Maximum value

*Chi-square $\left(\mathrm{x}^{2}\right)$ independence test

Analyzing collected data about subjects' salary satisfaction as a particular domain of job satisfaction, statistically significant dissatisfaction was found in total of 68 , i.e. $95.8 \%$ of study participants $(\mathrm{SD}, 1.9)$; the ambivalent stand towards satisfaction with salary was registered in two or 2.8 $\%$ of examined subjects ( $\mathrm{SD}, 0.7)$, while satisfaction within this domain was confirmed only by one participant, i.e. $1.4 \%(p<0.05)$. Considering participants' satisfaction with the possibility of promotion, a statistically significant dissatisfaction was found in total of 60 , i.e. $84.5 \%$ of subjects (SD, 1.8$)$; related to this particular domain of job satisfaction, the ambivalent stand was registered in two or $2.8 \%$ of participants (SD, 0.7), while statistically significant satisfaction with possibility of promotion was observed in nine, i.e.12.7\% of examined subjects (SD, 2.4), p <0.05. Regarding workplace benefits, statistically significant dissatisfaction was found in total of 66 , i.e. $93.0 \%$ of subjects (SD, 2.60) and the ambivalent stand took five, or $7.0 \%$ of participants (SD, 0.9); at the same time, satisfaction was not registered with any of the examined subjects towards this domain of job satisfaction $(p<0.05)$. Furthermore, statistically significant dissatisfaction with the possibility of rewarding was registered in a total of 52 study subjects, i.e. $73.2 \%$ (SD, 0.7), while ambivalent stand took 13 or $18.3 \%$ of participants (SD, 1.0); six subjects, i.e. $8.5 \%$ (SD, 0.7) were satisfied with the rewarding possibilities they have at the workplace ( $\mathrm{p}<0.05$ ). Statistically significant majority of subjects, 62 in total or $87.3 \%$ (SD, 2.4), expressed their dissatisfaction with working conditions; the ambivalent stand was registered in five i.e. $7.1 \%$ of study participants (SD, 0.7) and satisfaction within this domain was observed in four or $5.6 \%$ subjects $(\mathrm{SD}, 2.5), \mathrm{p}<0.05$. Further analysis of the collected data revealed also statistically significant dissatisfaction of subjects in the domain of nature of work, with a total of 36 i.e. $50.7 \%$ dissatisfied participants (SD, 2.1); ambivalent attitude towards this aspect of job satisfaction was found in total of 11 or $15.5 \%$ of participants (SD, 0.9), so the remaining 24 subjects, i.e. $33.8 \%$, expressed their satisfaction in relation to the nature of work (SD, 2.7), $\mathrm{p}<0.05$. Finally, by testing subjects' distribution based on satisfaction with professional communication, statistically significant dissatisfaction in total of 46 or $64.8 \%$ participants was found (SD, 2.3); ambivalent stand toward communication at the workplace took seven i.e. $9.9 \%$ of participants $(\mathrm{SD}, 0.8)$, while the satisfaction within this domain of job satisfaction was observed in total of 18 or $25.3 \%$ of examined subjects (SD, 2.7), $\mathrm{p}<0.05$. The statistical significance of obtained distributions in domains "supervision" and 
Int. J. of Health Serv. Res. and Policy (2019) 4(2): 84-94

"associates" was not established in this study $(\mathrm{p}>0.05)$. Statistically significant distributions of participants in different domains of job satisfaction are presented in Tab. 3 .

Table 3. Statistically significant distributions of participants in different domains of job satisfaction SALARY, $p<0.05$

\begin{tabular}{|c|c|c|c|c|c|c|c|}
\hline JS level $(x)$ & $\mathrm{N}$ & $\%$ & $\overline{\mathrm{x}}$ & SD & Med & Min. & Max. \\
\hline Dissatisfied (4-12 p.) & 68 & 95.8 & 4.9 & 1.9 & 4 & 4 & 12 \\
\hline Ambivalent (13-16 p.) & 2 & 2.8 & 15.5 & 0.7 & 15.5 & 15 & 16 \\
\hline Satisfied (17-24 b.) & 1 & 1.4 & - & - & - & - & - \\
\hline$\sum$ & 71 & 100.00 & & & & & \\
\hline \multicolumn{8}{|l|}{ PROMOTION, $p<0.05$} \\
\hline JS level $(x)$ & $\mathrm{N}$ & $\%$ & $\overline{\mathrm{x}}$ & $\mathrm{SD}$ & Med & Min. & Max. \\
\hline Dissatisfied (4-12 p.) & 60 & 84.5 & 5.6 & 1.83 & 5 & 4 & 11 \\
\hline Ambivalent (13-16 p.) & 2 & 2.8 & 13.5 & 0.7 & 13.5 & 13 & 14 \\
\hline Satisfied (17-24 b.) & 9 & 12.7 & 21.0 & 2.4 & 21.0 & 18 & 24 \\
\hline$\sum$ & 71 & 100.00 & & & & & \\
\hline \multicolumn{8}{|l|}{ BENEFITS, $p<0.05$} \\
\hline JS level $(x)$ & $\mathrm{N}$ & $\%$ & $\overline{\mathrm{x}}$ & SD & Med & Min. & Max. \\
\hline Dissatisfied (4-12 p.) & 66 & 93.0 & 6.8 & 2.6 & 6 & 4 & 12 \\
\hline Ambivalent (13-16 p.) & 5 & 7.0 & 13.6 & 0.9 & 13 & 13 & 15 \\
\hline Satisfied (17-24 b.) & 0 & 0 & - & - & - & - & - \\
\hline$\sum$ & 71 & 100.00 & & & & & \\
\hline \multicolumn{8}{|l|}{ REWARDING, $p<0.05$} \\
\hline JS level $(x)$ & $\mathrm{N}$ & $\%$ & $\overline{\mathrm{x}}$ & SD & Med & Min. & Max. \\
\hline Dissatisfied (4-12 p.) & 52 & 73.2 & 9.4 & 0.7 & 9 & 8 & 11 \\
\hline Ambivalent (13-16 p.) & 13 & 18.3 & 13.8 & 1.0 & 13 & 13 & 16 \\
\hline Satisfied (17-24 b.) & 6 & 8.5 & 18.1 & 0.7 & 18 & 17 & 19 \\
\hline$\sum$ & 71 & 100.00 & & & & & \\
\hline \multicolumn{8}{|c|}{ WORKING CONDITIONS, $p<0.05$} \\
\hline JS level $(x)$ & $\mathrm{N}$ & $\%$ & $\overline{\mathrm{X}}$ & SD & Med & Min. & Max. \\
\hline Dissatisfied (4-12 p.) & 62 & 87.3 & 6.4 & 2.4 & 5 & 4 & 12 \\
\hline Ambivalent (13-16 p.) & 5 & 7.1 & 15.0 & 0.7 & 15 & 14 & 16 \\
\hline Satisfied (17-24 b.) & 4 & 5.6 & 20.5 & 2.5 & 21 & 17 & 23 \\
\hline$\sum$ & 71 & 100.00 & & & & & \\
\hline \multicolumn{8}{|c|}{ NATURE OF WORK, $p<0.05$} \\
\hline JS level $(x)$ & $\mathrm{N}$ & $\%$ & $\overline{\mathrm{X}}$ & SD & Med & Min. & Max. \\
\hline Dissatisfied (4-12 p.) & 36 & 50.7 & 8.2 & 2.1 & 8 & 5 & 12 \\
\hline Ambivalent (13-16 p.) & 11 & 15.5 & 14.1 & 0.9 & 14 & 13 & 15 \\
\hline Satisfied (17-24 b.) & 24 & 33.8 & 20.5 & 2.7 & 19.5 & 17 & 24 \\
\hline$\sum$ & 71 & 100.00 & & & & & \\
\hline \multicolumn{8}{|c|}{ PROFESSIONAL COMMUNICATION, $p<0.05$} \\
\hline JS level $(x)$ & $\mathrm{N}$ & $\%$ & $\overline{\mathrm{x}}$ & SD & Med & Min. & Max. \\
\hline Dissatisfied (4-12 p.) & 46 & 64.8 & 7.5 & 2.3 & 7 & 4 & 12 \\
\hline Ambivalent (13-16 p.) & 7 & 9.9 & 13.7 & 0.8 & 14 & 13 & 15 \\
\hline Satisfied (17-24 b.) & 18 & 25.3 & 21.0 & 2.7 & 22 & 17 & 24 \\
\hline$\sum$ & 71 & 100.00 & & & & & \\
\hline
\end{tabular}

Note: $\mathrm{N}$-subjects in total; $\overline{\mathrm{x}}$-mean arithmetic value, $\mathrm{SD}$ - standard deviation, $\mathrm{CV} \%$ - variation coefficient, Med - median, Min. - minimum value, Max. - Maximum value

*Chi-square $\left(\mathrm{x}^{2}\right)$ independence test 


\section{Discussion}

Intensive care units represent specific departments of secondary level healthcare institutions, intended for hospitalization of critically ill patients [19]. In accordance with the purpose of intensive care units, it is quite understandable that those clinical departments are marked as exceptionally stressful working environment $[7,20]$. Considering the well-known fact that level of job satisfaction basically correlates with the workplace conditions and the nature of a particular job, it is expected that nurses working in intensive care units will be more dissatisfied comparing with their colleagues from other organizational units of healthcare institutions [14, 21]. This cross-sectional, non-experimental psychometric study included 71 critical care nurses in total, all working in different intensive care units of one Belgrade's university hospital at the moment of entering the research. The examined subjects mean age was 33.8 years, with slightly lower mean values in males, as compared to females - 36.3 years. Similar to other researches that involve nurse population, in this study female participants, have been found to prevail over males [22]. By choosing a traditionally female occupation, males can experience role conflict and consequent job dissatisfaction [23]. Although some studies indicate that job dissatisfaction is more common in male nurses, this claim could not be proven by our study, as well as the results of some researches suggesting an increase in job satisfaction among nurses with aging [24$26]$.

In general, terms, job satisfaction can be seen as an affective attitude of an individual to its own work, degree of commitment to work, or the subjective importance of work for a particular individual. Depending on the contribution degree of different work factors to the satisfaction when performing professional activities, general job satisfaction can be also defined as a sum of satisfaction with certain aspects of the particular job [27]. Unlike similar researches that established the middle level of general job satisfaction among the examined population of nurses [28, 29], a statistically significant strong predomination of general job dissatisfaction among participants has been established in our study, amounting to more than three-quarters of dissatisfied subjects in total. Increasing knowledge about the importance of health professionals' job satisfaction should have a global social significance, because professional dissatisfaction may seriously affect the quality of performed patient care [14, 30]. Although authors of studies from different world countries suggest that the degree of job satisfaction among ICU nurses is always lower compared to nurses of other hospital departments because of higher levels of perceived job stress [31,32], such a significant representation of general dissatisfaction among participants always points to the existence of serious problems and low level of work motivation in particular profession, even though it is an employee sample from one institution, like in our study.

As expected, almost all subjects of the examined sample were most dissatisfied with their salary - a factor of work that does not depend on the institution management but reflects the economic situation in the country and the organization of its entire health system. Despite confirmed significant correlation between job satisfaction and monthly salary, material aspects of work are still one of the main problems in achieving job satisfaction in the nursing profession, not only in Serbia but also in the surrounding countries $[33,34]$. Adequate material compensation for realized work is the essential prerequisite of job satisfaction and efficient work of health workers, since the time of Hippocrates [35]. In a few former Yugoslav countries, inadequate salary is nowadays the main reason of losing work motivation in the nursing profession and recruiting to other EU countries. The divergence between the contemporary system of nursing education and the existing institutional work systematization represents another important reason of job dissatisfaction, loss of work motivation and intention to leave among 
nurses in these countries [34]. The global social underestimation of healthcare professions, especially the nursing profession, can be seen by further analysis of the data collected in our study. Besides low salary, study participants also indicated next reasons for job dissatisfaction: absence of benefits for performed work (no satisfied subject), inadequate working conditions and small opportunities for promotion (more than four-fifths of examined subjects in total), as well as absence of rewarding for achieved work results (approximately three-quarters of dissatisfied subjects in total). All the abovementioned job satisfaction domains have a significant impact on the level of work motivation, and therefore on the efficiency and quality of the performed professional activities [3, 36].

However, besides above-mentioned domains of job satisfaction that are regulated by legal acts and mostly cannot be easily influenced, there are also those whose correction can easily increase the satisfaction of doing a particular job. By analyzing collected data, it is found that approximately half of our study participants are not satisfied with the nature of the work they are performing. If we exclude the objectively large influence of professional stress in intensive care units and impact of all the previously mentioned job satisfaction domains, it is obvious that adequate professional orientation and choosing a profession in accordance with individual characteristics of personality represent the key factors for a later higher level of job satisfaction. Implementation of educative programs for achieving an assertive way of communication could also contribute in increasing level of job satisfaction among participants of our study, as approximately two-thirds of them in total expressed dissatisfaction with the current way of professional communication. Quality of communication as a factor of increasing job satisfaction has been the subject of many different studies. The results of domestic research conducted among intensive care units staff indicate that even 37\% of professional errors have been caused by poor communication between physicians and nurses [37].

\subsection{Study limitations}

The limitation of the study originates from a relatively small sample and the fact that the study included ICU nurses of a single healthcare institution during a particular period. In order to reach more scientifically significant results, it is necessary to carry out prospective research on a larger sample of subjects from several healthcare institutions.

\section{Conclusion}

Based on the analysis of collected data, a high level of job dissatisfaction among participants of our study was founded. Participants were most dissatisfied with the salary, but they also expressed dissatisfaction in other domains of job satisfaction - work benefits, working conditions, promotion opportunities, rewarding, nature of work and the way of professional communication. Considering obtained results in the light of the competent literary sources' allegations which suggest that job satisfaction level reliably indicate the level of work motivation at the same time, we concluded that work motivation in the observed sample was very poor at the moment of conducting this study, clearly indicating the need for a more comprehensive research of work motivation among Serbian nursing practitioners in future.

\section{Conflict of interests}

Authors have no conflicts of interest to declare. 


\section{References}

[1] Nikić, D., Aranđelović, M., Nikolić, M., Stanković, A., "Zadovoljstvo poslom kod zdravstvenih radnika (In Serbian)", Acta Medica Medinae, 47, 9-12, 2008.

[2] Locke, EA, Latham, GP, "Work motivation and satisfaction: light at the end of the tunnel", Psychological science, 1(4), 240-246, 1990.

[3] Stepanov, S., Paspalj, D., Butulija, M., "Motivacija zaposlenih kao ključni pokazatelj zadovoljstva poslom (In Serbian)", Ekonomija, teorija i praksa, 9(2), 53-67, 2016.

[4] Tella, A., Ayeni, CO., Popoola, SO., "Work motivation, job satisfaction, and organizational commitment of library personnel in academic and research libraries in Oyo State, Nigeria", Library philosophy and practice (e-journal), 9(2), 1-16, 2007.

[5] Olafsen, AH, Halvari, H., Forest, J., Deci, EL., "Show them the money? The role of pay, managerial needs support, and justice in a self-determination theory model of intrinsic work motivation", Scandinavian journal of psychology, 56(4), 447-457, 2015. DOI: 10.1111/sjop.12211

[6] Bonenberger, M., Aikins, M., Akweongo, P., Wyss, K., "The effects of health worker motivation and job satisfaction on turnover intention in Ghana: a cross-sectional study", Human resources for health, 12(1), 1-12, 2014. DOI: 10.1186/1478-4491-12-43

[7] Knežević, B., Golubić, R., Milošević, M., Matec, L., Mustajbegović, J., “Zdravstveni djelatnici u bolnicama i stres na radu: istraživanje u Zagrebu (In Croatian)", Sigurnost, 51(2), 85-92, 2009.

[8] Novak, V., "Sindrom izgaranja medicinskih djelatnika u radu s umirućim pacijentima (In Croatian)", Sestrinski glasnik / Nursing Journal, 19, 189-195, 2014. DOI: 10.11608/sgnj.2014.19.041

[9] Bovier, PA., Perneger, TV, "Predictors of work satisfaction among physicians", Eur. J. Public Health, 13, 299-305, 2003.

[10] Schaufeli, WB., Burnout: a short socio - cultural history, in: Burnout, fatigue, exhaustion (Ed. S. Neckel), Springer international publishing, pp. 105-127, 2017.

[11] Poncet, MC. et al., "Burnout syndrome in critical care nursing staff", Am J Respir Crit Care Med,175(7), 698-704, 2007. DOI: 10.1164/rccm.200606-806OC

[12] Ivković, J., "Sindrom izgaranja i uticaj na naš život (In Serbian)", Sestrinska reč, 19, 16-17, 2015.

[13] Van Dijk, FJH., Swaen, GMH., "Fatigue at work", Occup Environ Med, 60(1), 1-2, 2003. DOI: 10.1136/oem.60.suppl_1.i1

[14] Myhren, H., Ekeberg, Ø., Stokland, O., "Job satisfaction and burnout among intensive care unit nurses and physicians", Crit Care Res Pract, Article ID:786176, 6 pages, 2013. DOI: $10.1155 / 2013 / 786176$.

[15] Cooper, CL., Sloan, SJ., Williams, S., Occupational stress indicator-management guide, NFERNelson, Windsor, 1988.

[16] Larrabee, JH., Janney, MA., Ostrow, CL., Withrow, ML., Hobbs, GR., Burant, C., "Predicting registered nurse job satisfaction and intent to leave", The Journal of Nursing Administration, 33(5), 271283, 2003.

[17] Jovanović, J., Modeli stresa na poslu (In Serbian), in: Ergonomija i medicina rada, Panevropski univerzitet “Apeiron”, Banja Luka, 2009.

[18] Job Satisfaction Survey; JSS Translations (database on the Internet), Available from: http://shell.cas.usf.edu/ pspector/scales/jsstranslate.html 
[19] Manojlović, S., Hitna stanja u internoj medicini za medicinske sestre (In Serbian), Zavod za udžbenike, Beograd, 2011.

[20] Buljubašić, A., Sindrom sagorijevanja među zdravstvenim djelatnicima (In Croatian), master thesis, Sveučilišni odjel zdravstvenih studija, Split, Croatia, 2015.

[21] Mealer, M., Jones, J., Newman, J., McFann, KK., Rothbaum, B., Moss, M., "The presence of resilience is associated with a healthier psychological profile in intensive care unit (ICU) nurses: results of a national survey", International Journal of Nursing Studies, 49(3), 292-299, 2012. DOI: 10.1016/j.ijnurstu.2011.09.015

[22] Milutinović, D., Grujić, N., Jocić, N., "Identifikacija i analiza stresogenih faktora na radnom mestu medicinskih sestara - komparativna studija četiri klinička odeljenja”, Med Pregl, 62(1/2), 68-73, 2009. DOI: 10.2298/MPNS0902068M

[23] Hsu, HY., Chen, SH., Yu, HY., Lou, JH., "Job stress, achievement motivation and occupational burnout among male nurses", Journal of advanced nursing, 66(7), 1592-1601, 2010. DOI: 10.1111/j.1365-2648.2010.05323.x

[24] Sochalski, J., "Nursing shortage redux: turning the corner on an enduring problem", Health Affairs, 21(5), 157-164, 2002.

[25] Letvak, S., "Health and safety of older nurses", Nursing outlook, 53(2), 66-72, 2005. DOI: 10.1016/j.outlook.2004.09.005

[26] Ernst, ME., Franco, M., Messmer, PR., Gonzalez, JL., "Nurses' job satisfaction, stress, and recognition in a pediatric setting”, Pediatric nursing, 30(3), 219-228, 2004.

[27] Mladenović, V., Marković, Z., "Emocionalni profil i zadovoljstvo poslom zdravstvenih radnika (In Serbian)", Engrami, 33(2), 5-17, 2011.

[28] Lorber, M., Skela Savič, B., "Job satisfaction of nurses and identifying factors of job satisfaction in Slovenian hospitals", Croat. Med. J., 53(3), 263-270, 2012. DOI: 10.3325/cmj.2012.53.263

[29] Golbasi, Z., Kelleci, M., Dogan, S., "Relationship between coping strategies, individual characteristics and job satisfaction in a sample of hospital nurses: cross-section questionnaire survey", Int J Nurs Stud, 45, 1800-1806, 2008.

[30] Piers, RD., et al., "Perceptions of appropriateness of care among European and Israeli intensive care unit nurses and physicians", JAMA, 306(24), 2694-2703, 2011. DOI: 10.1001/jama.2011.1888

[31] Tao, H., Ellenbecker, CH., Wang, Y., Li, Y., "Examining perception of job satisfaction and intention to leave among ICU nurses in China", International Journal of Nursing Sciences, 2(2), 140148, 2015. DOI: 10.1016/j.ijnss.2015.04.007

[32] Norbeck, JS., "Perceived job stress, job satisfaction, and psychological symptoms in critical care nursing”, Res Nurs Health, 253-259, 1985.

[33] Abduelazeez, AEA., Tahir, MM., "Job satisfaction and related factors among intensive care nurses in governmental hospitals at Khartoum state - Sudan", J Comm Pub Health Nurs, 2(2), 114, 2016. DOI: 10.4172/2471-9846.1000114

[34] Jović, D., Knežević, D., Egeljić Mihailović, N., "Problemi diplomiranih medicinskih sestara u svakodnevnoj praksi (In Serbian)", Sestrinski žurnal - Nursing Journal, 2(2), 5-10, 2015. DOI: 10.7251/SEZ0215005J

[35] Eldstein, L., The Hippocratic Oath: text, translation and interpretation, The University of Chicago Press Books, Chicago (IL), 1943. 
[36] Buntak, K., Drožđek, I., Kovačić, R., "Materijalna motivacija u funkciji upravljanja ljudskim potencijalima (In Croatian)”, Tehnički glasnik, 7(1), 56-63, 2013.

[37] Brestovački, B., "Poor communication as a potential cause of professional errors", Journal of the Association of Serbian Neurologists, 21(3-4), 75-81, 2013. 